\title{
SEX DETERMINATION BY SACRAL INDEX FROM HUMAN SACRA
} OF SAURASHTRA REGION

\section{Pravina Jagani, V.J.Akbari, Sanjay Chavda, Ashish Rathva.}

1,4 Tutor, Department of Anatomy, P.D.U. Medical College, Rajkot, Gujarat, India.

*2,3 Assistant professor, Department of Anatomy, P.D.U. Medical College, Rajkot, Gujarat, India.

\section{ABSTRACT}

Introduction: The identification of sex in human skeletal remains is an important component of many anthropological investigations and forensic science. Sex determination using sacrum is often considered with various available parameters and indices when dealing with human skeleton remains. Sacral index is the most important criteria for sex determination using sacrum. Present study aims at determining the significance of sacral index in sex determination from sacra of saurashtra region.

Materials and Methods: 120 (84 male and 36 female) adult human sacra of known sex from Saurashtra region was included in present study. Ventral straight length and maximum breath of sacrum was measured, sacral index calculated, Demarking points for these parameters were used for identification of sex of sacrum.

Results: In males sacral index varies from 90.38 to 119.36 , with mean value of 103.49 and standard deviation was found to be 8.52. In females sacral index varies from 92.86 to 141.33 , with mean value of 116.97 and standard deviation was found to be 8.52 . In statically significant range(Mean $\pm 3 \mathrm{SD}$ ) maximum value of male sacral index was 121.76 and minimum value of female index was 91.40 . These two points were accepted as demarking points.

Conclusion: Significant differences has been observed in the sacral index of males and females of Saurashtra region. Sacral index is higher in females than in males. On the basis of present study it can be concluded that in Saurashtra region sacrum having sacral index less than 91.40 is definitely of male whereas sacrum having sacral index more than 121.76 is definitely of female. However not a single parameter could identify sex of $100 \%$ of the bones.

KEY WORDS: Sacrum, Sacral index, Sex determination

Address for Correspondence: Dr. V.J.Akbari, 21, Sattelite Park, Street-1, Nr Govind Ratna Bunglows, Bh Tapovan School, Gowardhan Chowk BRTS, $150 \mathrm{ft}$ Ring Road, Rajkot, Gujarat, India.

Contact No. :+919099091453 E-Mail: vrajakbari80@gmail.com

Access this Article online

Quick Response code

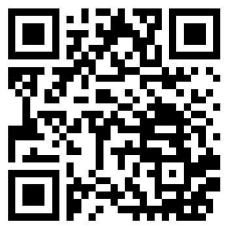

DOI: $10.16965 /$ ijar.2018.154

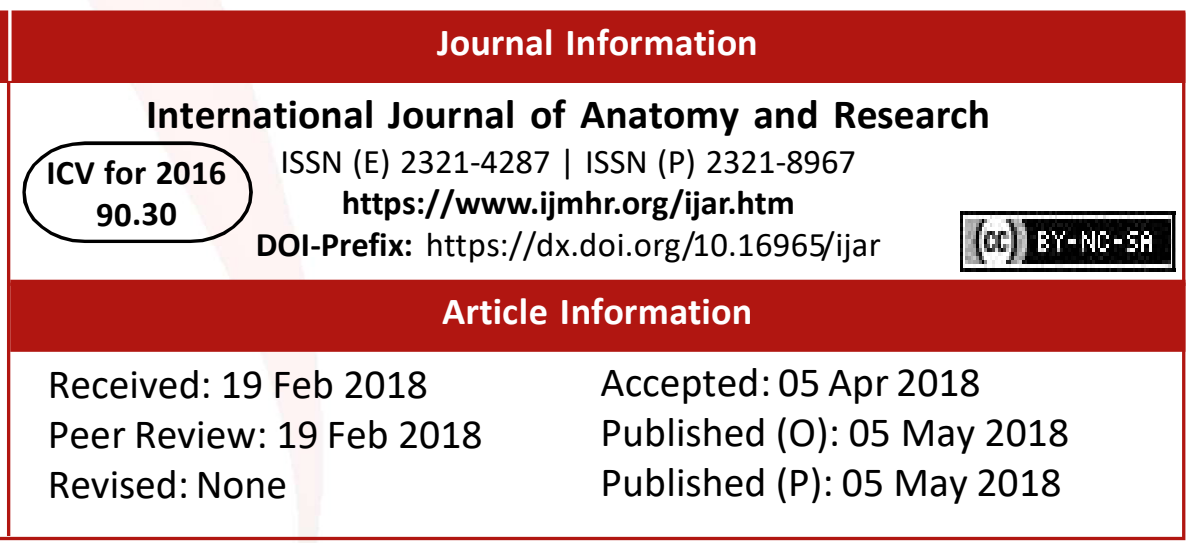

\section{INTRODUCTION}

The identification of sex in human skeletal remains is an important component of many anthropological investigations and should be based on measurements and observations on the entire skeleton to be meaningful (Stewart 1954)[1]. It is also very useful in forensic science. The human sacrum is large triangular bone wedged between two hip bones. As per Frazer [2], female bone is broader than the male and shows a different anterior curve, in the males curve is almost uniform from above downwards but in females it is more marked at the lower part and the upper part is almost flat.

Sex determination using sacrum is often considered with various available parameters 
and indices when dealing with human skeleton remains.

Sacral index is the most important criteria for sex determination using sacrum[3].

Sacral Index $=$ Width of Sacrum $\times 100 /$ Height of Sacrum.

Aim: Present study aims at determining the significance of sacral index in sex determination from sacra of saurashtra region.

\section{MATERIALS AND METHODS}

The present study was conducted on fully ossified 120 adult human sacra of saurashtra region obtained from M.P.Shah Medical college, Jamnagar and P.D.U.Medical college, Rajkot. Out of them 84 were male sacra and 36 were female sacra. Only Sacra with five segments were measured and bones showing the evidence of anatomical malformations were excluded.

To calculate sacral index mid ventral straight length(maximum length) and maximum breadth of sacrum were measured using vernier caliper.

Midventral straight length was measured by applying points of vernier caliper to middle of promontory and middle of anteroinferior border of fifth sacral vertebre as shown in figure 1.(Hadlicka 1952)[3].

Maximum breadth of sacrum was measured by applying stem of caliper to upper surface of body of first sacral vertebra and greatest expanse of lateral masses of sacrum was measured as shown in figure 2.(Hardlika,1952)[3].

Sacral index was calculated and data were statistically analysed. Mean, Standard deviation and demarking point were calculated. Significance of results were evaluated by applying ' $\mathrm{t}$ ' and ' $p$ ' values.

Fig. 1: Measurement of midventral straight length of sacrum.

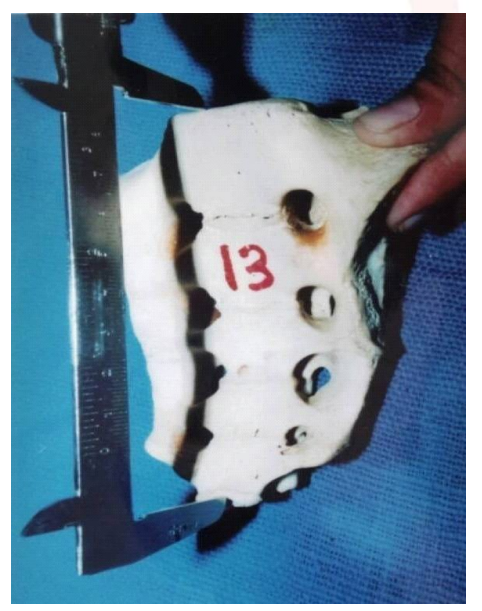

Fig. 2: Measurement of maximum breadth of sacrum.

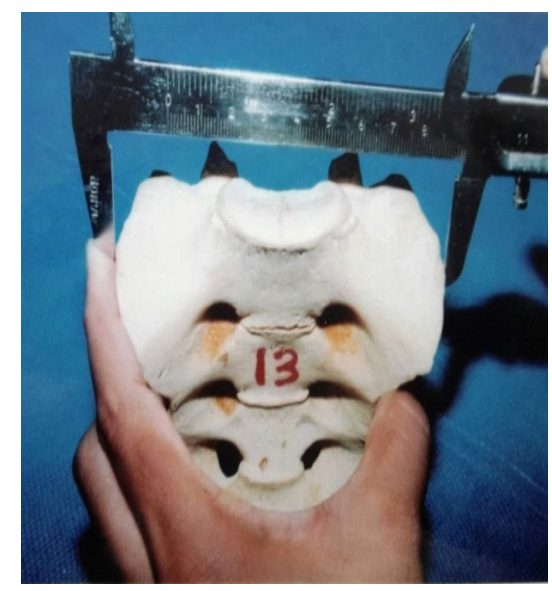

\section{RESULTS}

After measuring maximum length and maximum breadth of each of 84 male and 36 female sacra data was tabulated and sacral index was calculated.

The sacral index of majority of sacra of saurashtra region falls in platyhieric group(sacral index more than 100)[4].

Table 1: Sexual dimorphism of sacral index.

\begin{tabular}{|c|c|c|}
\hline & Male & Female \\
\hline No. Of Bones observed & 84 & 36 \\
\hline Range & $90.38-119.36$ & $92.86-141.33$ \\
\hline Mean & 103.49 & 116.97 \\
\hline SD & 6.09 & 8.52 \\
\hline Mean \pm 3 SD & $85.22-121.76$ & $91.40-142.53$ \\
\hline Demarking point & $<91.40$ & $>121.76$ \\
\hline $\begin{array}{c}\text { Percentage beyond } \\
\text { demarking point }\end{array}$ & $2(1.67)$ & $7(5.83)$ \\
\hline
\end{tabular}

$\mathrm{t}=8.56 \mathrm{t}>3.55$, so $\mathrm{P}<0.001$

In males sacral index varies from 90.38 to 119.36 , with mean value of 103.49 and standard deviation was found to be 8.52 .

In females sacral index varies from 92.86 to 141.33 , with mean value of 116.97 and standard deviation was found to be 8.52 .

It was observed that females had greater sacral index than males.

Overlaping range: Table- 1 and Chart-1 showes that $91.40-121.76$ is common range of sacral index for both male and female. So overlapping range is $91.40-121.76$.

Demarking point: In Present study statastically significant range was decided by $\mathrm{M} \pm 3$ SD because this range covers maximum sample size and gives more accuracy of result. Table- 1 shows 




ranges of 85.22-121.76 and 91.40-142.53 for male and female sacral indices respectively. Maximum value of male sacral index was 121.76 and minimum value of female index was 91.40 . These two points were accepted as demarking points.

That means all observation less than 91.4 were definitely of male sacra and all observation more than 121.76 were definitely female sacra.

\section{DISCUSSION}

Same study was conducted by Raju et al in Varansi region [5], Mishra et al in Agra region [6] and Davivongs V. in Australian aboriginal sacra [7].

Table 2: Statistical comparision of male sacral index of present study with that of others work.

\begin{tabular}{|c|c|c|c|c|}
\hline & $\begin{array}{c}\text { Present study } \\
(\mathrm{n}=84)\end{array}$ & $\begin{array}{c}\text { Raju et al. } \\
(\mathrm{n}=33)\end{array}$ & $\begin{array}{c}\text { Mishra et al } \\
(\mathrm{n}=74)\end{array}$ & $\begin{array}{c}\text { Davivongs } \\
(\mathrm{n}=50)\end{array}$ \\
\hline Range & $90.36-119.35$ & $74.72-126.98$ & $90-108$ & $86.9-123.2$ \\
\hline Mean & 103.49 & 100.85 & 98.21 & 104.16 \\
\hline SD & 6.09 & 8.71 & 4.89 & 8.93 \\
\hline Mean \pm 3 SD & $85.22-121.76$ & $74.72-126.98$ & $83.54-112.86$ & -- \\
\hline Demarking Point & $<91.40$ & $<88.38$ & $<96.84$ & --- \\
\hline $\begin{array}{c}\text { Percentage beyond } \\
\text { demarking point }\end{array}$ & 1.66 & 0 & 39.2 & -- \\
\hline
\end{tabular}

For statistical study and comparison Table-2, 3 $\& 4$ were constructed to show bisexual dimorphism of sacral index in males and females with respect to range, Mean, S.D., Mean \pm 3 SD, Demarking point \& percentage beyond demarking point.

Int J Anat Res 2018, 6(2.2):5203-06. ISSN 2321-4287
Table 3: Statistical comparision of female sacral index of present study with that of others work.

\begin{tabular}{|c|c|c|c|c|}
\hline & $\begin{array}{c}\text { Present study } \\
(\mathrm{n}=36)\end{array}$ & $\begin{array}{c}\text { Raju et al. } \\
(\mathrm{n}=11)\end{array}$ & $\begin{array}{c}\text { Mishra et al } \\
(\mathrm{n}=42)\end{array}$ & $\begin{array}{c}\text { Davivongs } \\
(\mathrm{n}=50)\end{array}$ \\
\hline Range & $92.86-141.33$ & $88.38-134.40$ & $103-131.25$ & $96.2-140.0$ \\
\hline Mean & 116.97 & 111.39 & 117.84 & 115.4 \\
\hline SD & 8.52 & 7.67 & 7 & 10.39 \\
\hline Mean \pm 3 SD & $91.40-142.53$ & $88.38-134.4$ & $96.84-138.84$ & -- \\
\hline Demarking Point & $>121.76$ & $>126.98$ & $>112.88$ & -- \\
\hline $\begin{array}{c}\text { Percentage beyond } \\
\text { demarking point }\end{array}$ & 5.83 & 0 & 80.1 & -- \\
\hline
\end{tabular}

Table 4: ' $\mathrm{t}$ ' value and ' $\mathrm{P}$ ' value of present study and other studies.

\begin{tabular}{|c|c|c|c|c|}
\hline & Present study & Raju et al. & Mishra et al & Davivongs \\
\hline ' $t$ ' value & 8.56 & 3.82 & 17.68 & --- \\
\hline 'P' value & $<0.001$ & $<0.001$ & $<0.001$ & --- \\
\hline
\end{tabular}

Mean sacral index of Male sacra of saurashtra region (103.49) was higher than that of Agra region (98.21) and that of Varanasi region (100.85).

Mean sacral index of Female sacra of saurashtra region (116.97) was lower than that of Agra region (117.84) and higher than that of Varanasi region (111.39).

Davivongs (1963) in his study of Australian aboriginal sacra had reportedmean sacral index to be 104.16 in Male which was slightly higher than that of Saurashtra region(103.49). Mean sacral index of female sacra was found to be 115.49 which was slightly lower than that of 
Saurashtra region(116.97).

Mean sacral index was more in females than males and difference was stastically highly significant (' $P$ ' value $<0.001$ ).

\section{CONCLUSION}

Significant differences has been observed in the sacral index of males and females of Saurashtra region. Sacral index is higher in females than in males. In other words female sacra are relatively broader than male sacra.

On the basis of present study it can be concluded that in Saurashtra population sacrum having sacral index less than 91.40 is definitely of male whereas sacrum having sacral index more than 121.76 is definitely of female.

Obtained ' $\mathrm{t}$ ' value and ' $\mathrm{P}$ ' value in present study showed that there was a significant difference between sacral index of male and female.

Due to great overlapping in sacral index for male and female in present study, we can say that not a single parameter could identify the sex of sacrum with $100 \%$ accuracy. Hence it can be concluded that for determination of sex of sacrum, multiple parameters should be employed to attain $100 \%$ accuracy.

\section{Conflicts of Interests: None}

\section{REFERENCES}

[1]. Stewart TD. Sex determination of the skeleton. American journal of Physical Anthropology. 1954;12:385392.

[2]. Frazer JE. Anatomy of Human Skeleton.3rd ed. London: Churchill Livingstone; 1933.p.3.

[3]. Stewart TD. Hrdlicka's Practical Anthropometry:.4th edition. The Wistar Institute of Anatomy \& Biology, Philadelphia. 1952:172,

[4]. Comas J. Charles C. Manual of Physical Anthroplogy, Thomas spring field, Illinois, USA. : 1961;415-416.

[5]. Raju PB, Singh S, Padmanabhan R. Sex determination and sacrum. Journal of Anatomical Society of India.1980;30:13-15.

[6]. Mishra SR, Singh PJ, Agrawal AK, Gupta RN. Identification of sex of sacrum of Agra region. J Anat Soc of India 2003;52:132-6.

[7]. Davivong V. The Pelvic Girdle of the Australian Aborigenes; sex differences and sex determination. Am J Phys Anthropo 1963;21:443-55.

How to cite this article:

Pravina Jagani, V.J.Akbari, Sanjay Chavda, Ashish Rathva. SEX DETERMINATION BY SACRAL INDEX FROM HUMAN SACRA OF SAURASHTRA REGION. Int J Anat Res 2018;6(2.2):5203-5206. DOI: 10.16965/ijar.2018.154 